\title{
RITKA RÓMAI TÁRGYAK EGY KVÁD TELEPEN: VÁGYOTT LUXUS VAGY EGYSZERÜ NYERSANYAG? Új kutatások Ipolytölgyes-TSz-major lelőhelyen
}

\section{Soós Eszter ${ }^{1}$ - Juhász Lajos ${ }^{2}$ - Mag Hella ${ }^{3}$ - Molnár RóberT ${ }^{4}$}

Magyar Régészet 9. évf. (2020), 2. szám, pp. 28-36. doi: https://doi.org/10.36245/mr.2020.2.2

Az Ipoly folyó völgyében a római korban germán kvád csoportok telepedtek meg. A lelöhelyek elhelyezkedését a topográfiai munkák alapján jól ismerjük, de a feltárt leletegyüttesek részletes kiértékelése egyelöre hiányzott. Az Ipolytölgyes-TSz-major lelöhelyen 2017-töl lehetöségünk nyilt újabb régészeti kutatásokat folytatni. A feltárt leletanyag és a non-destruktív kutatások során elökerült tárgyak alapján a korábban ismertnél gazdagabb képet kapunk egy Pannonia határán élt germán közösségröl.

\section{BEVEZETÉS}

A római korban az Ipoly völgyében germán kvád csoportok telepedtek meg. A kvádok a Kr. u. 1. századtól a 4. század végéig népesítették be a mai Szlovákia nyugati részét, a Garamtól keletre, és Magyarország területére eddigi adataink alapján csak a markomann háborúk (Kr. u. 166-180) idejétől települtek. Jellemző kerámiaformáik Miskolc környékéig megtalálhatók. A szlovák kutatás eredményeivel szemben Magyarországról szinte hiányoznak a feldolgozott lelőhelyek (Soós \& TANKÓ, 2018, 291-296). Az Ipoly völgyének településhálózata a topográfiai munkák alapján jól ismert (MRT 1993), de régészeti feltárás során dokumentált települések értékelése máig késik.

2017 tavaszán a váci Tragor Ignác Múzeum munkatársai régészeti feltárást végeztek az IpolytölgyesTSz-major lelöhelyen a területen müködő MONO-Ipolyfabrik Kft. megbízásából. Az őskori jelenségek mellett egy római kori germán épület részlete is napvilágra került, melynek hatoszlopos szerkezete megegyezett az 1960-as években Erdélyi István által ugyanitt feltárt épületével: mindkettő a kvád területek leggyakoribb típusába sorolható (ERDÉLYi \& LAMiovÁ-SchmiedLovÁ, 1971). A 2017-es leletanyag értékeléséhez szükséges volt elemezni a korábban feltárt, de csak részben publikált leleteket. Az ipolytölgyesi kerámia leletanyag így összevethetővé vált a nyugat-szlovákiai kvád törzsterület jellegzetességeivel.

A lelőhely délnyugati része már nem kutatható, de a Szob-Parassapuszta út keleti oldalán lehetőségünk nyílt szisztematikus terepbejárást és fémkeresős kutatást végezni, amelyben a váci Tragor Ignác Múzeummal együttmüködő önkéntesek is részt vettek.

A váci múzeumban 2017 óta az érdeklődő civilekkel való közös munka egyre szervezettebb: a régészeti munka részleteinek megismerése mellett anyagismereti előadások, terepbejárások segítik az együttműködést. Követendő példaként áll előttünk a Ferenczy Múzeumi Centrum közösségi régészeti programja, valamint a résztvevők által 2019-ben alapított Közösségi Régészeti Egyesület tevékenysége (RÁcz, 2017; 2019). Szükséges kiemelni a múzeum gyüjteménykezelőjének, Kóka Istvánnak a lelőhely-felderítési tapasztalatát is, aki több, mint egy évtizede tartó, elsősorban Nagybörzsönyre és környékére koncentráló tevékenységének köszönhetően számos új lelőhellyel, illetve információval gazdagította a régióról való ismereteinket.

Ezúton szeretnénk megköszönni Kővári Klára és Jakucs János régészeknek, Kékesi Márk régészhallgatónak, Kóka István régészeti gyüjteménykezelőnek, továbbá Bartos Ferenc, Gulyás Attila, Konecsni Béla, Petyánszki Attila és Szijjártó Gábor önkénteseknek a lelőhely kutatása során nyújtott terepi segítségét.

\footnotetext{
Pécsi Tudományegyetem, BTK TTI, Régészet Tanszék. E-mail: soos.eszter@pte.hu

Eötvös Loránd Tudományegyetem, BTK, RI, Ókori Régészeti Tanszék. E-mail: juhasz.lajos@btk.elte.hu

Tragor Ignác Múzeum, Vác. E-mail: mag.hella@muzeumvac.hu

E-mail: robert.molnar87@gmail.com
} 
Soós Eszter - Juhász Lajos - Mag Hella - Molnár Róbert • Ritka római tárgyak egy kvád telepen

\section{A LELŐHELY KUTATÁSA}

Ipolytölgyes-TSz-major lelöhely az Ipoly keleti és a Cserge- (Ganádi-) patak északi partján, a dombhát nyugati és déli lejtőjén húzódik 1. kép).

1967-ben kis felületü feltárást végzett a helyszínen az MTA Régészeti Intézete. A rövid jelentések és a szlovák nyelven megjelent publikáció csak pár kiemelt tárgy alapján vont le következtetéseket (ERDÉLYI \& LAMIOVÁ-SchMIEDLOVÁ, 1971).

Az 1970-es és 1980-as években terepbejárások során pontosításra került a többkorszakos lelőhely kiterjedése (MRT 1993, 116, 10/1. 1h). 2001 februárjában Kővári Klára végzett kis felületű feltárást az akkor épülő üzem délkeleti részén, mely során középső neolitikus jelenségeket azonosított.

2017-ben a MONO-Ipolyfabrik Kft. épületeinek bővítésébe kezdtek. Sajnos a munkák kezdetéről csak utólag értesült a múzeum, így első helyszíni szemlénk idejére a lelőhely délnyugati részén már mintegy $1000 \mathrm{~m}^{2}$-es területen, több méter mélységben kitermelték a földet.

Három területen végeztünk régészeti kutatásokat: a gyártól északra, a parkoló területén (2. kép 1), ahol az objektumok nagy részét az elfedés miatt csak a felszínen dokumentálhattuk. Itt középső neolitikus település nyoma került elő néhány réz-, illetve késő bronzkori jelenség mellett. A hulladékraktár (2. kép 2) területén bronzkori objektumok jelentkeztek kis számban. Az

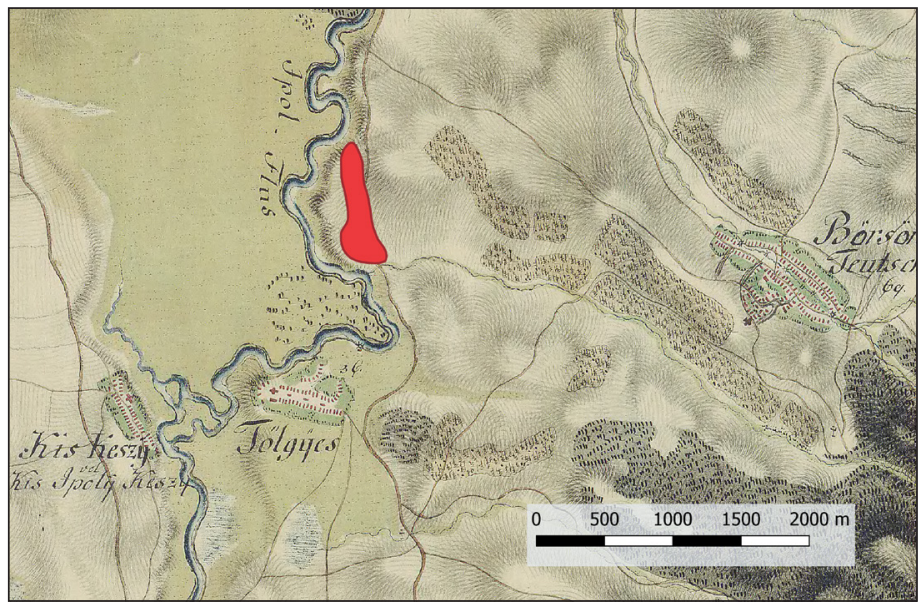

1. kép. Ipolytölgyes-TSz-major lelöhely az Elsö Katonai Felmérésen

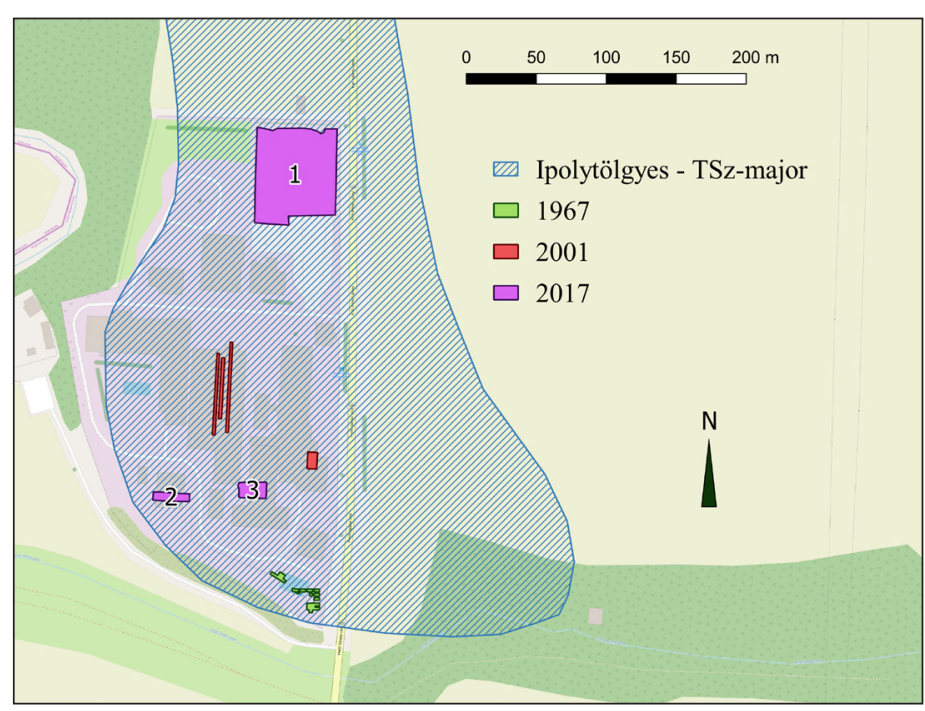

2. kép. A lelöhely déli kiterjedése és a feltárással kutatott területek ipari csarnok építésénél (2. kép 3) egy római kori épület délkeleti sarkát dokumentáltuk, melyen kívül csak réz- és bronzkori telepjelenségek kerültek elö. A terület régészeti intenzitása alapján valószínüsítjük, hogy a déli, mintegy $1000 \mathrm{~m}^{2}$-es lelőhelyrészlet elpusztítása jelentős információveszteséget okozott.

\section{A TEREPBEJÁRÁS EREDMÉNYEI}

Az ásatás mellett a lelőhely müúttól keletre eső részén fémkereső müszeres kutatással egybekötött terepbejárást végeztünk, melynek során számos római kori kerámia- és fémtárgyat gyüjtöttünk.

Adataink pontosításához 2019. március 7-én és szeptember 12-én szisztematikus kutatásokat is folytattunk. A leletek helyét Garmin 60 és Garmin 62 típusú kézi GPS készülékekkel rögzítettük.

Célunk elsőként a lelőhely kiterjedésének pontosítása volt. Ennek megállapításához D-É irányban, 25 m-es közönként jártuk le a területet. Minden összegyüjtött tárgy helyét rögzítettük, a leletanyagot 100 m-es egységenként csomagoltuk el. Terepi kitüzést nem végeztünk, a 100×100 és 50×50 m-es egységek határát a kézi GPS készülékek alapján az EOV virtuális háló adta (a módszerről részletesen: MESTERHÁzy, 2013). A lejárt területet és a leletanyag szóródását térképre vetítve egyértelmű lett, hogy a lelőhely kelet felé legalább 70-100 m-rel meghaladja a korábban rögzített kiterjedését (3. kép). 
Soós Eszter - Juhász Lajos - Mag Hella - Molnár Róbert • Ritka római tárgyak egy kvád telepen

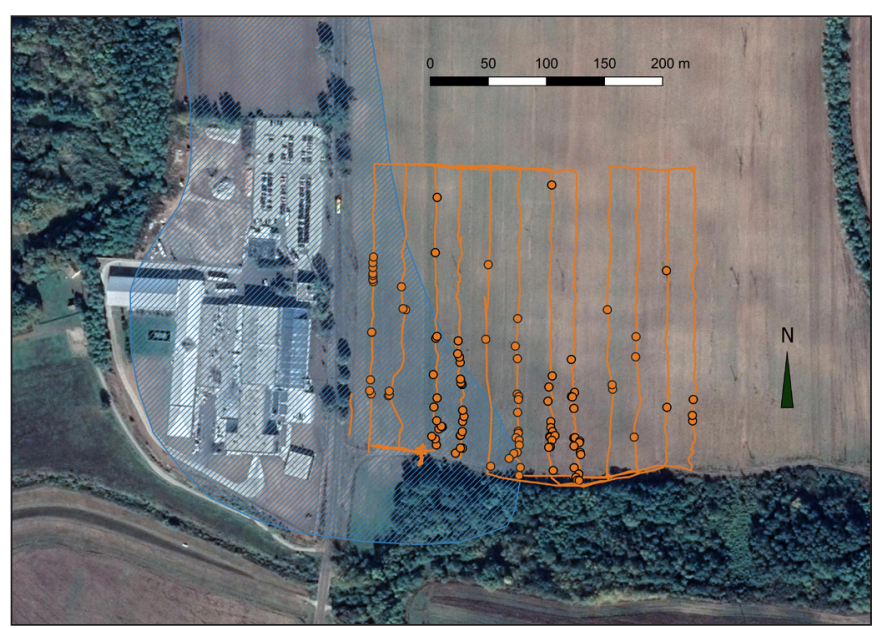

3. kép. Ipolytölgyes-TSz-major lelőhely kiterjedése és a 2019. március 7-ei terepbejárás kerámia leletanyagának szóródása

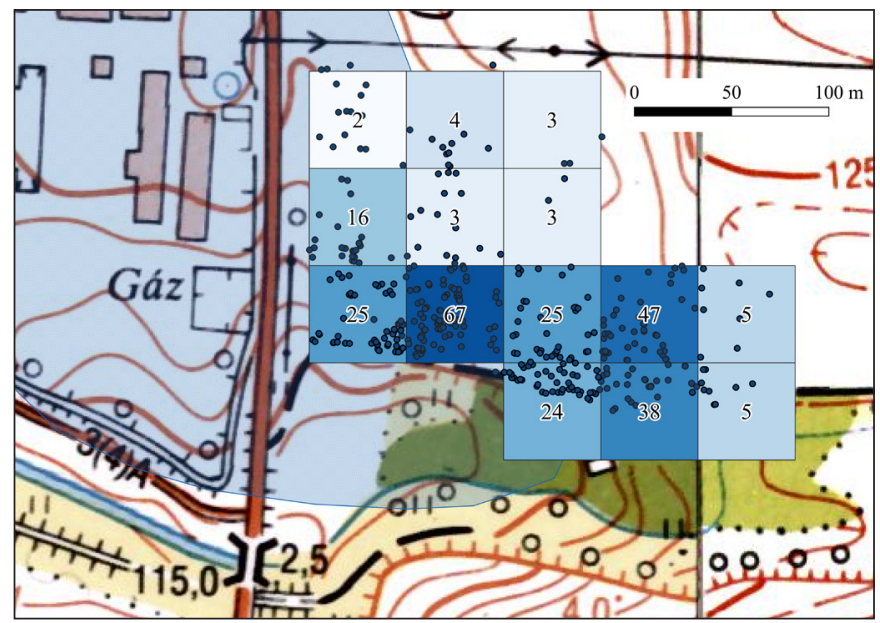

5. kép. A bronzkori leletanyag szóródása az intenziven bejárt területen. (töredékszám)

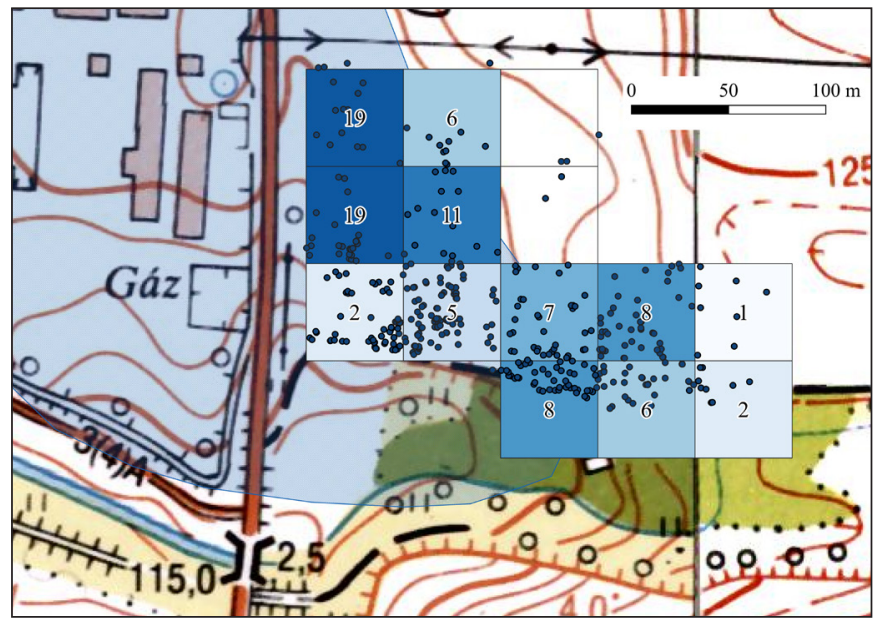

4. kép. A neolitikus leletanyag szóródása az intenzíven bejárt területen (töredékszám)

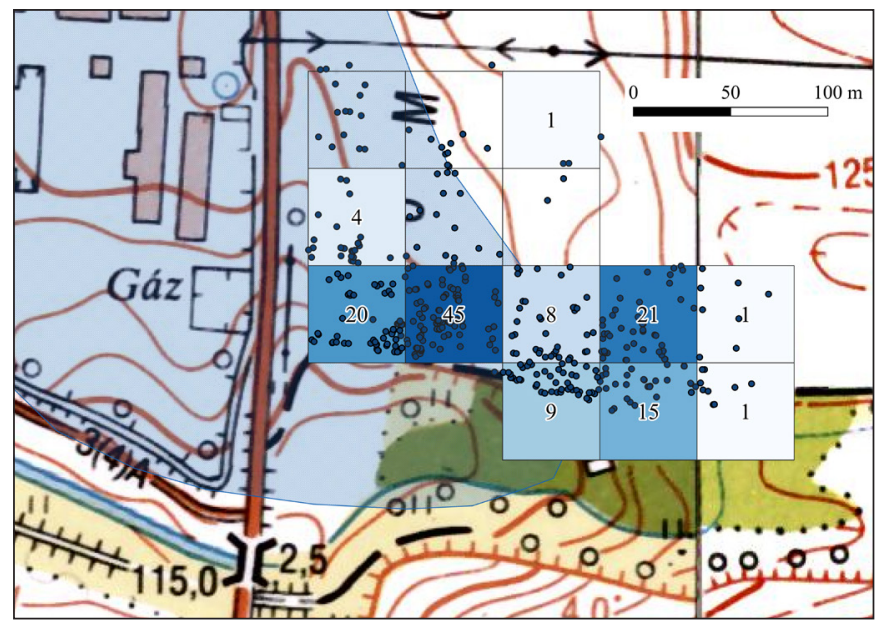

6. kép. A római kori leletanyag szóródása az intenzíven bejárt területen (töredékszám)

A leletekben leggazdagabb részen ezt követően intenzív bejárást is folytattunk az egyes régészeti korszakok lehatárolására, a római kori megtelepedés helyszínének pontosítására. Vizsgálati egységnek $50 \times 50$ m-es négyzeteket határoztunk meg, az egyes négyzeteken belül minden lelet helyét rögzítettük, majd közös csomagolási egységbe helyeztük.

Térképre vetítve a különböző korú leletanyag térbeli sűrüsödését, a viszonylag kis kutatott felületen is lehetett eltéréseket megfigyelni. A neolitikus töredékek nagyobb számban a terület északnyugati részén, a müút mellett jelentkeztek (4. kép). A késő bronzkori, kora vaskori leletanyag szóródása inkább a Csergepatak folyásához igazodott (5. kép). A római kori germán megtelepedés szintén a Cserge-patak partját követve, attól 50-100 m távolságra húzódott (6. kép).

\section{A FÉMKERESŐS KUTATÁS EREDMÉNYEI}

A 2017-től végzett kutatás eredményeként a lelőhelyről több fémtárgy, fibula, római érem ismert, mint ahány eddig összesen publikálásra került a magyarországi kvád településterületröl. ${ }^{5}$

Az 1971-ben publikált számszeríjfibula és egy Exner III 24 típusú, email berakásos korongfibula mellett 2017-2019 között legnagyobb számban a Kr. u. 3. századtól keltezhető, Almgren VI. csoportba sorolható, egytagú, aláhajtott és oldalt hajtott lábú fibulák kerültek elő (7. kép 1-2). Ezek az egyszerü, felsőhúros típu-

A fibulák többsége a 2017-es gyüjtés során került napvilágra, ekkor előkerülésük pontos helyét nem volt lehetőségünk GPSszel rögzíteni. 
Soós Eszter - Juhász Lajos - Mag Hella - Molnár Róbert • Ritka római tárgyak egy kvád telepen

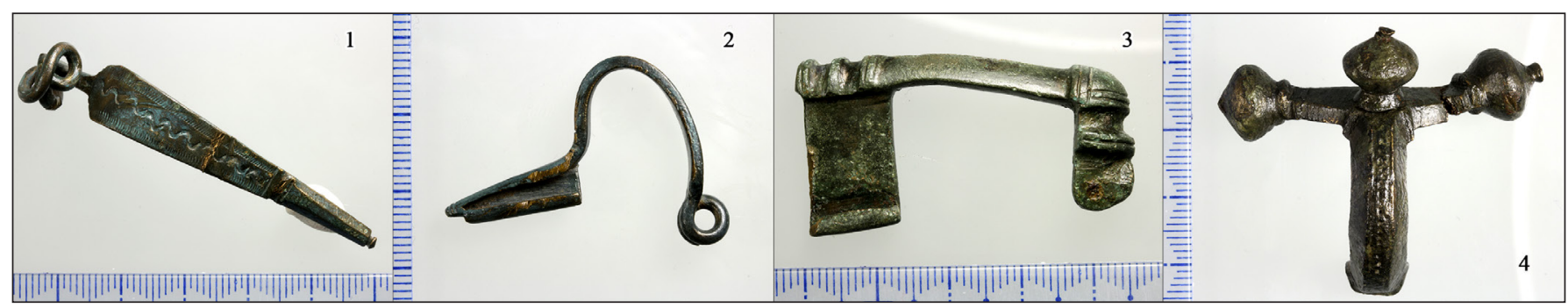

7. kép. Fémkeresös kutatás során gyüjtött fibulák. 1-2: aláhajtott lábú fibulák, 3: germán térdfibula, 4: római hagymagombos fibula töredéke. (Fotó: Orlik Edit)

sok széles körben elterjedtek germán és szarmata területen is, néhány díszített példánynak pontos analógiája hozható markomann-kvád lelöhelyekröl (VARSIK, 2011, 220, Abb. 102, 6).

Napvilágot láttak viszonylag ritka típusok is. A germán térdfibulát (7. kép 3) általában a markomann háborúk időszakában feltünő, északi germán impulzussal hozzák összefüggésbe (MĄczYŃsKA, 2001). Jóval későbbi, Kr. u. 4. századi horizontot mutatnak a római hagymagombos fibulák töredékei (7. kép 4). Elökerülésük germán települések környékén ritka, de nem szokatlan, egyelőre nem lehet megállapítani, milyen összefüggésbe hozhatók a kvád teleppel.

$\mathrm{Az}$ ipolytölgyesi kutatások legkülönlegesebb leletei a módosabb római réteg életmódját tükröző bronztárgyak töredékei (8. kép).

Egy hengeres, tömör bronzfül vége vésett vonalakkal kialakított állatfejet, valószínủleg macskafélét formáz. A töredék kis mérete ellenére pontosan meghatározható, egy Eggers 83 típusú mély, hengeres bronzmedence függesztőkarikát tartó veretének darabja (9. kép). ${ }^{6}$ A mosdótálként használt edény a dunai provinciákban a Kr. u. 3. század első felében volt gyakori, a legtöbb példány településekről vagy depóleletből ismert (SEDLMAYER, 2016, 383). A germán Barbaricumban ezzel szemben az edénytípus elsősorban a leggazdagabb, ún. Leuna-Haßleben

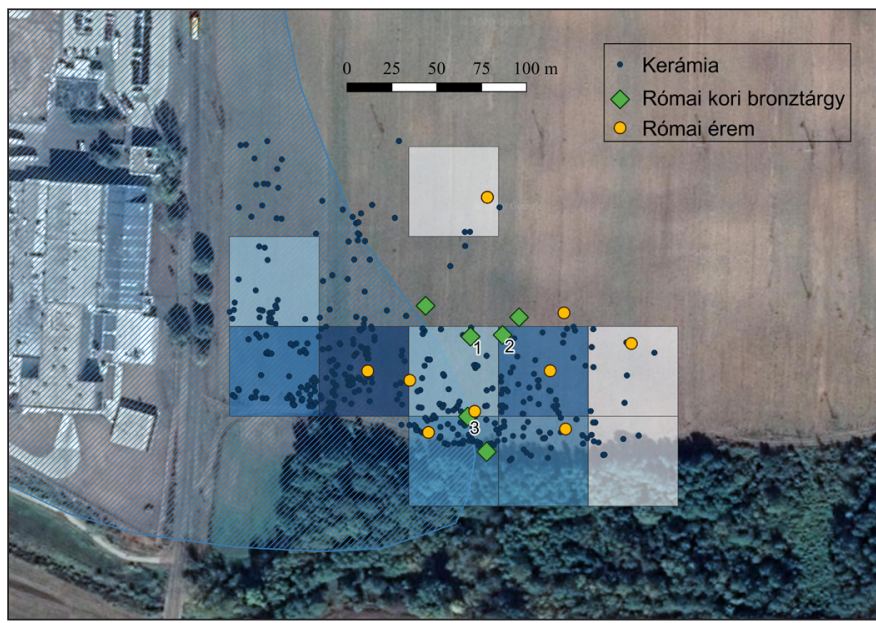

8. kép. A bronztárgyak és római érmek szóródása. 1: tripus büszt, 2: bronz kisplasztika töredéke, 3: bronzedény töredéke

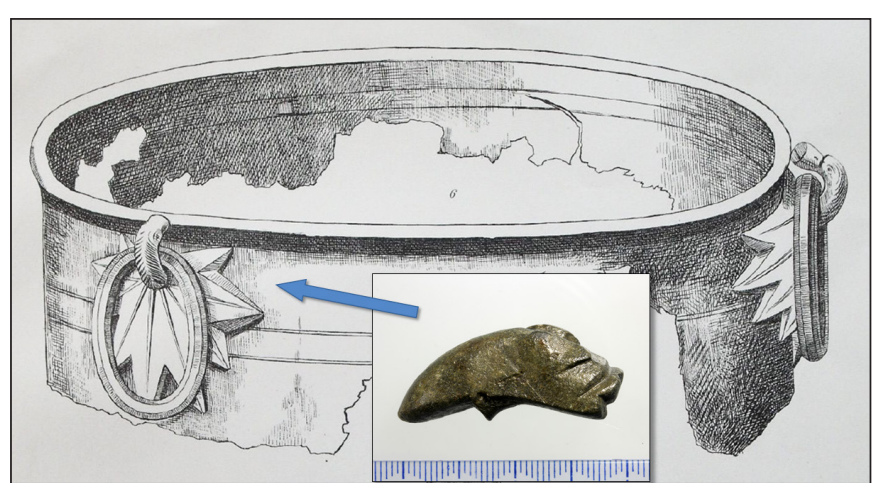

9. kép. Az ipolytölgyesi bronztál töredéke és a sackraui III. temetkezésböl elökerült tál rajza

(GEMPLER 1888, Taf. V, 6 után, fotó: Orlik Edit). körhöz tartozó, Kr. u. 3. századi elit temetkezések mellékleteként kerül napvilágra, mint a sackraui I. és III. temetkezés, és krakovany-strážei II. sír (QUAST, 2009, Abb. 14, Abb. 26). Barbár településeken ebben az időszakban a római bronzedények kimondottan ritkák, dunai germán területröl eddig összesen három Eggers 83 típusú tál töredéke ismert szórványként (IvÁn \& ÖlveczKi, 2012, 215, 9. kép 7; SedlMAyer, 2016, 390).

Szándékos vágás nyomát viseli egy római bronz kisplasztika töredéke (10. kép). A sarut viselö, jobb lábfejet ábrázoló tárgy az alakot kissé előrenyújtott lábbal, lábujjhegyen állva ábrázolja. A tartás leggyakrabban a Lar I-es típusánál fordul elő, amely táncoló testtartásban, tunikában, felemelt kezében rhytont, a leengedettben pedig leginkább situlát vagy paterát tartó figuraként jeleníti meg (BARTUS, 2015, 77-78).

Talán a legimpozánsabb darab egy állítható fesztávolságú római állvány (tripus) egyik lábának tetejét

6 A meghatározásban Jan Jílek (Masaryk University, Brno) segített, melyet ez úton is köszönünk. 
Soós Eszter - Juhász Lajos - Mag Hella - Molnár Róbert • Ritka római tárgyak egy kvád telepen

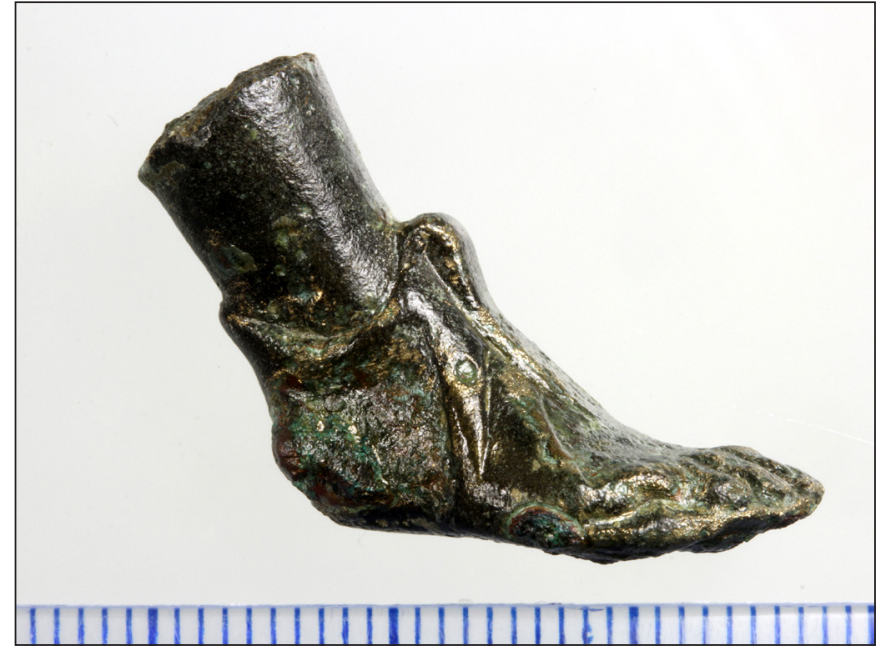

10. kép. Római bronz kisplasztika töredéke (Fotó: Orlik Edit)

díszítő bronzplasztika. A $6 \mathrm{~cm}$ magas, erősen kopott felületủ koronázó büszt egy fríg sapkát viselő ifjút, valószínüleg Attist formálja (11. kép). A római három- és négylábú, összecsukható állványok a kora császárkorban áldozat bemutatására szolgáló füstölőoltárokként is funkcionáltak. A tripusok szerepe a Kr. u. 3. századtól megváltozott: gyártásuk Itáliából egyre inkább átkerült az északi provinciákba, ahol - ahogy Pannoniában is - a provinciális elit étkezőhelységeiben, lakomáin hangsúlyozták a vendéglátók jólétét és gazdagságát vagy mosdóállványként használták őket (részletesen: KLATT, 1995). Az előbbi funkcióval összefüggésben a díszítésüknél is gyakran bacchikus motívumokat alkalmaztak.

A római tripusok barbár környezetben az Eggers 83 típusú bronztálakhoz hasonlóan a Kr. u. 3. századi elit temetkezésekből ismertek, mint Mušov, Krakovany-Stráže, Ostrovany vagy Gommern (QuAst, 2009, 17-19; BECKER, 2010). A tripusok és az akasztókarikával ellátott Eggers 83 tálak eredeti funkciójukban összekapcsolódtak: ezt a táltípust lehetett az állvány díszítő büsztjeinek kampójára akasztani. Barbár környezetben készletként való használatuk azonban nem minden esetben igazolható, a sackraui I. sírban quadripus (négylábú állvány) volt Eggers 83 tállal, melynek három akasztókarikáját nem lehetett az állványhoz rögzíteni, a II. sírba pedig a tál önmagában, asztal nélkül volt helyezve (12. kép) (GEMPLER, 1887, Taf. II-IV; 1888, Taf. V, 6).

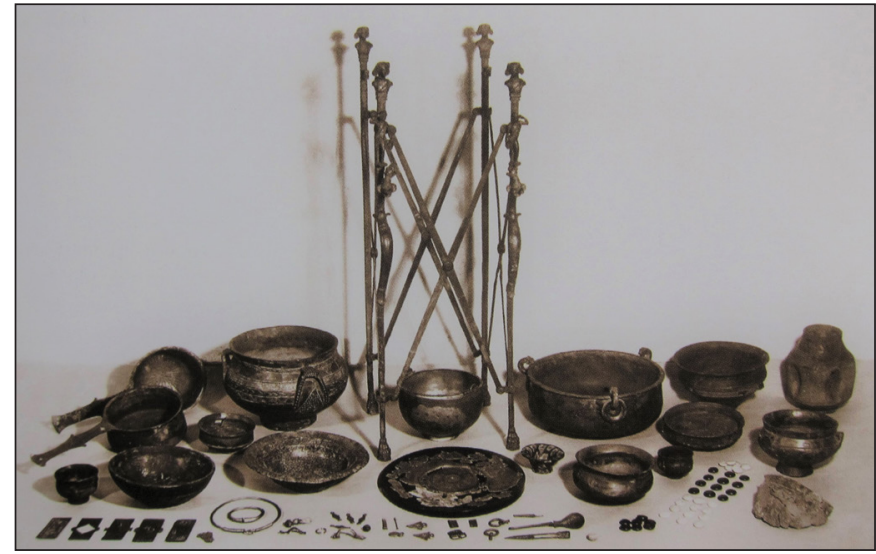

12. kép. Sackrau I. sír leletanyaga (QUAST 2009, Abb. 14).

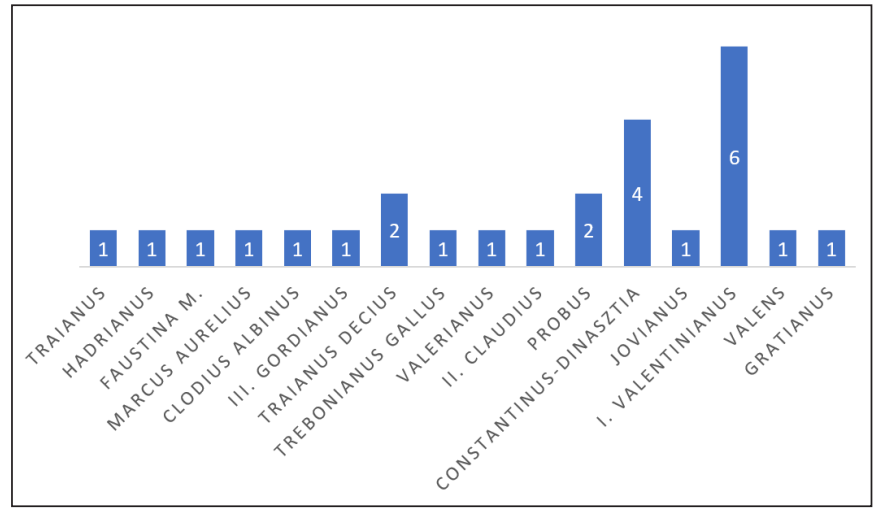

13. kép. Az Ipolytölgyesen elökerült érmek kronológiai megoszlása 
Soós Eszter - Juhász Lajos - Mag Hella - Molnár Róbert • Ritka római tárgyak egy kvád telepen

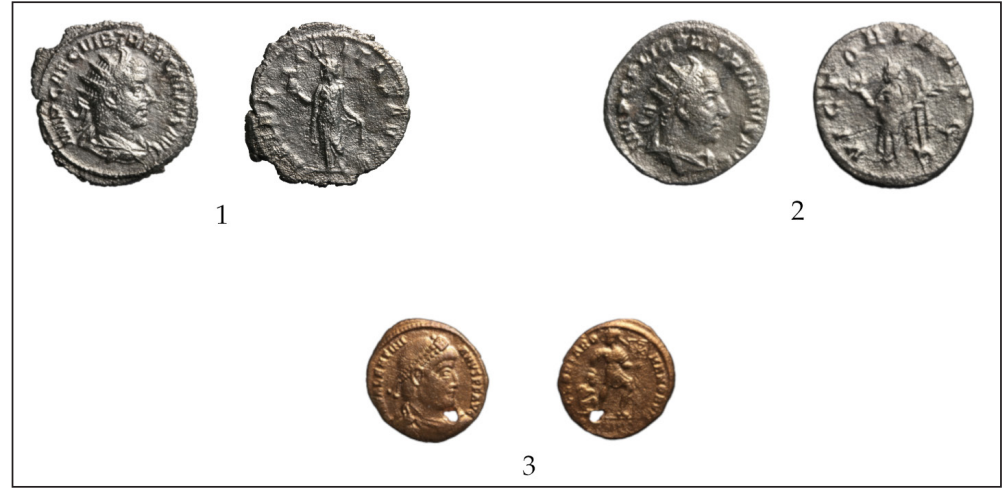

14. kép. Érmek 1. Trebonianus Gallus, 2. Valerianus, 3. Valentinianus (Fotó: Orlik Edit)

Germán településeken nem jellemzők a tripusok töredékei. Az ipolytölgyesi példányon kívül csak Borsodszirákról, egy feltehetően szintén kvád jellegü település területéről ismert egy Bacchust ábrázoló koronázó büszt (Tóтн, 2014, 161-162, Fig. 3, 1).

Az ipolytölgyesi kutatások során összesen $33 \mathrm{db}$ érem került elö, amelyek Traianustól a Valentinianus-dinasztiáig tartó 250 éves periódust ölelik át (13. kép).

A Kr. u. 2. századra 5 érem keltezhetö, amelyek közül ritka Clodius Albinus denariusa. Nyolc érem tehető a 3. századra, köztük egy jó megtartású Trebonianus Gallus antoninianus (14. kép 1) és Valerianus antoninianusa (14. kép 2). A Constantinus-dinasztia idejére négy érem keltezhető, ebből kettő Kr. u. 355-363 közé tehető. Ritka lelet a rövid ideig uralkodó Jovianus (Kr. u. 363-364) sirmiumi verete. A Valentinianus-ház nyolc éremmel van képviselve, így ezzel ez a leghangsúlyosabb korszak. ${ }^{7}$ Hat érem I. Valentinianusé, egy-egy Valensé és Gratianusé. További négy pénz csak általánosan keltezhető a 4. századra, három volt teljesen meghatározhatatlan. Címlet szerint tizenegy ezüstpénz volt (három denarius, hat antoninianus és két aurelianus). Kisebb címletből három sestertius, tizenhét AE 3-as és két AE 4-es került elö. Ehhez jön még két ókori hamisítvány is: egy denarius subaeratus és egy sestertius limes falsa. A verdék közül Róma kilenc, Siscia nyolc éremmel van képviselve, amelyet Viminacium követ kettő, majd Sirmium és Cyzicus egy-egy verettel.

Érdekes, hogy tizenegy éremnél lehetett utólagos megmunkálás nyomait megfigyelni. Hat darab esetében legalább a lapka harmada hiányzott. Egynél csak az érem egynegyede maradt meg, a többit szabályosan levágták róla. A hasonló darabokat nyersanyagként vagy súlyuk és anyaguk szerint is alkalmazhatták a helyi árucserében (ELSCHEK, 2007, 146; JuHÁsz, 2017, 251-254). Öt érmet lyukkal is elláttak. ${ }^{8}$ Egy érem lyukasztás és csonkítás nyomait is mutatta. Még folyik a környező területekről származó pénzleletek feldolgozása, mely lehetőséget ad majd az érmek alaposabb elemzésére.

\section{ÖSSZEGZÉS}

Az elmúlt évek kutatásaival együtt az Ipolytölgyes-TSz-major lelöhely vált a legrészletesebben elemzett kvád településrészletté az Ipoly magyarországi szakaszán.

A feltáráson napvilágot látott leletanyag a Kr. u. 2. század végétől a 3. század első feléig, a terepbejárás és a fémkeresős kutatás során gyűjtött fém- és éremanyag a Kr. u. 2-4. század közé keltezhető.

A római provinciális edénytípusok: a westerndorfi terra sigillaták (GABLER, 1968, 230, 4. kép 4-6, GABLER \& VADAY, 1986, 17), a szürke agyagbevonatos tálak (Pannonische Glanztonwäre), a vörös festett edények, dörzstál, horpasztott oldalú edények (Faltenbecher) darabjai és egy szálrátét díszű kehely töredéke a Severus-korban gyakran megtalálhatók kvád telepeken (15. kép) (VARSIK, 2011, 219, Abb. 100).

A kerámiaanyag nagy része helyi, kézzel formált áru. A finom anyagú, fényezett felületü, feketére égetett, behúzott peremü tálak, tálkák, fazekak és a durvább anyagú tálak és fazekak alkották a telepen a fazekasárut (15. kép). Ipolytölgyesen hiányzik a finom edények barbotinos, meanderes és befésült, ívelt vonalkötegekkel való díszítése. A jelenség hátterében kronológiai okok állhatnak, az alig 15 km-re elhelyezkedő, markomann háborúktól keltezett párkányi telepen még a finom kerámia gazdag díszítése figyelhető meg (BELJAK, 2010, Obr. 12, 1-10, Obr. 22; VARSIK, 2011, 218, 222).

Az éremanyag pontosabb keltezésre nem alkalmas, azonban Trebonianus Gallus és Valerianus nagyon

Egy további GLORIA ROMANORVM hátlapos érem esetében nem lehetett eldönteni, hogy az a Valentinianus-dinasztiához vagy esetleg későbbi uralkodókhoz tartozott-e.

8 A másodlagosan megmunkált érmek lehetséges felhasználási módjairól lásd JuHÁsz, 2019, 102-105. 
Soós Eszter - Juhász Lajos - Mag Hella - Molnár Róbert • Ritka római tárgyak egy kvád telepen

szép megtartású érmei mindenképp egy gyors földbekerülést vagy legalább egy nagyon mérsékelt forgalmi időszakot indikálnak. Megjegyzendő, hogy a pénzek harmadánál utólagos megmunkálás jelei voltak megfigyelhetök.

A leletanyagból érdemes kiemelni az Eggers 83 bronzedény és a tripus töredékét. Mindkét tárgytípus legnagyobb valószínúséggel a Kr. u. 3. század első felére keltezhetö, ám nem lehet kizárni, hogy később, akár a 4. században is földbe kerülhettek. Értelmezésüket egy, a limestől 15 km-re fekvő barbár telepen nem lehet elválasztani kronológiai hely-

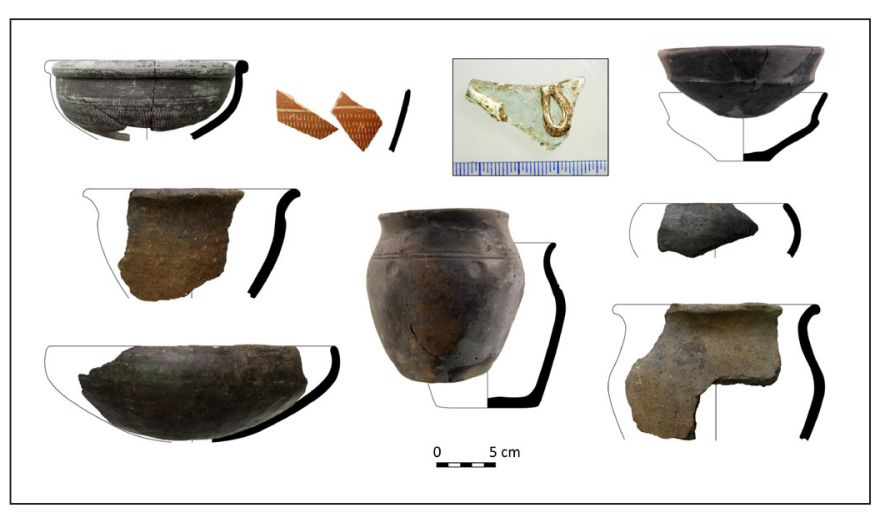

15 kép. Ipolytölgyes-TSz-major, római import és helyi kerámiatípusok (Fotó: Orlik Edit, Soós Eszter) zetüktől. Helga Sedlmayer felvetette, hogy a római bronzedények germán területek felé irányuló kereskedelme lezárulhatott közvetlenül a markomann háborúk után (SEDLMAYER, 2016, 394). Ez alapján az ipolytölgyesi tárgyak kereskedelmi termékként nehezen értelmezhetőek, annál is inkább, mert a típusok az elit temetkezéseken kívül nem voltak jellemző sírmellékletek. Eredeti szerepükben való használatuk töredékes állapotuk miatt sem feltételezhető. Nem lehet kizárni, hogy germán tulajdonba egy, a provincián belüli eredményes fosztogatás zsákmányaként kerültek, ahol feldarabolva csupán nyersanyag-utánpótlásként szolgáltak a helyi fémmüvességhez. A nemzetközi kutatás eddigi adatai alapján valószínüsíthető, hogy római bronztárgyak a germán Barbaricumban - függetlenül attól, hogy eredeti kontextusukban kimondottan magas értéket képviseltek - nem csupán politikai kapcsolatokat vagy reprezentatív értéket, hanem egyszerü nyersanyag utánpótlást is jelentettek (BECKER, 2003).

\section{BIBLIOGRÁFIA}

Bartus, D. (2015). Bronzistenek. Római figurális bronzplasztika Brigetióban. Acta Archaeologica Brigetionensia Ser. I. Vol. 8. Komárom: Klapka György Múzeum.

Becker, M. (2003). Klasse und Masse - Überlegungen zu römischem Sachgut im germanischen Milieu. Germania 81, 277-288.

Becker, M. (2010). Das Fürstengrab von Gommern. Veröffentlichungen des Landesamtes für Archäologie Sachsen Anhalt 63. Halle: Landesamt für Denkmalpflege und Archäologie Sachsen-Anhalt.

Beljak, J. (2010). Germánske osídlenie v Štúrove a na dolnom Pohroní v staršej dobe rímskej. Germanische Besiedlung im Štúrovo und unterem Gran-Gebiet in der älteren römischen Kaiserzeit. Zborník. Slovenského Národného Múzea C IV, 141-174.

Elschek, K. (2007). Römische Münzen entlang der Bernsteinstrasse im Slowakischen Marchgebiet nördlich von Carnuntum (Westslowakei) und ein Beleg der Sekundärvewendung von römischen Münzen. Slovenská Numizmatika 18, 143-156.

Erdélyi, I. \& Lamiová-Schmiedlova, M. (1971). Osada z doby rímskej v Ipolytölgyesi v Mad’arsku. Siedlung aus der römischen Zeit in Ipolytölgyes in Ungarn. Východoslovenský pravek 2, 51-72.

Gabler, D. (1968). Terra sigillaták a Kelet-Pannóniával szomszédos Barbaricumban. A Barbaricum importjának néhány kérdése. Sigillaten im Ostpannonien benachtbaren Barbaricum. Archeologiai Értesitö 95, 211-242. 
Soós Eszter - Juhász Lajos - Mag Hella - Molnár Róbert • Ritka római tárgyak egy kvád telepen

Gabler, D. \& Vaday, A. (1986). Terra Sigillata im Barbaricum zwischen Pannonien und Dazien. Fontes Archaeologici Hungariae. Budapest: Akadémiai kiadó.

Gempler, W. (1887). Der Fund von Sackrau. Breslau: Museum schlesischer Altertümer.

Gempler, W. (1888). Der II. und III. Fund von Sackrau. Breslau: Museum schlesischer Altertümer.

Iván, R. \& Ölveczki, R. (2012). New Germanic settlement finds in the Western part of the Great Rye Island. In Bíró Sz. \& Molnár A. (szerk.), Ländliche Siedlungen der römischen Kaiserzeit im mitterlen Donauraum (pp. 297-316). Győr: Mursella.

Juhász, L. (2017). Burning money - a coin hoard from Brigetio. Dissertationes Archaeologicae 3 (5), 251-258. http://dx.doi.org/10.17204/dissarch.2017.241

Juhász, L. (2019). Perforated Roman coins from the Aquincum-Graphisoft cemetery. In L. Juhász (ed.), Numismatica Pannonica I. Proceedings of the conference held by the Antique Numismatic Workshop on the 10th September 2018 at the Hungarian Numismatic Society Budapest, Hungary (pp. 91-110). Budapest: Hungarian Numismatic Society, Antique Numismatic Workshop. https://doi.org/10.37790/anhs.1.7

Klatt, U. (1995). Römische Klapptische. Drei- und vierbeinige Stützgestelle aus Bronze und Silber. Kölner Jahrbuch 28, 349-573.

Mączyńska, M. (2001). Einige Fibeln südlicher Herkunft im Hortfund von Łubiana in Pommern. In E. Istvánovits \& V. Kulcsár (eds.), International Connections of the Barbarians of the Carpathian Basin in the $1^{\text {st }}-5^{\text {th }}$ centuries A.D. Proceedings of the international conference held in 1999 in Aszód and Nyiregyháza (pp. 77-93). Aszód-Nyíregyháza: Osváth Gedeon Museum Foundation - Jósa András Museum.

Mesterházy, G. (2013). Regionális léptékü terepbejárás módszertani lehetőségeinek vizsgálata Magyarországon. Methodology and potentials of field surveys on a regional scale in Hungary. Archaeológiai Értesitö 138, 265-279. https://doi.org/10.1556/ArchErt.138.2013.10

MRT 9 = Dinnyés, I., Kővári, K., Kvassay, J., Miklós, Zs., Tettamanti, S. \& Torma, I. (1993). Pest Megye Régészeti Topográfiája. A szobi és a váci járás. XIII/2. kötet. Budapest: Akadémiai Kiadó.

Quast, D. (2009). Wanderer zwischen den Welten. Die germanischen Prunkgräber von Stráže und Zakrzów. Begleitbuch zur Ausstellung im Römisch-Germanischen Zentralmuseum, 10. September 2009 bis 10. Januar 2010. Forschungen am Römisch-Germanischen Zentralmuseum Band 6. Mainz: Verlag des RömischGermanischen Zentralmuseums.

Rácz, T. Á. (2017). Fémkeresősök a múzeum kötelékében. Közösségi régészeti modell építése Pest megyében. Magyar Régészet 6 (3) [2017 ösz], 1-7.

Rácz, T. Á. (2019). Közösségi régészet. Egy új kutatási eljárás születése. Múzeumcafé: a múzeumok magazinja 13 (4), 149-157.

Sedlmayer, H. (2016). Die Spektren römischer Bronzegefässe in Noricum und dem angrenzenden Barbaricum im Vergleich - Typen des 2./3. Jahrhunderts n. Chr. In H-U. Voß \& N. Müller-Scheeßel (eds.), Archäologie zwischen Römern und Barbaren. Zur Datierung und Verbreitung römischer Metallarbeiten des 2. und 3. Jahrhunderts n. Chr. im Reich und im Barbaricum - ausgewählte Beispiele (Gefäße, Fibeln, Bestandteile 
Soós Eszter - Juhász Lajos - Mag Hella - Molnár Róbert • Ritka római tárgyak egy kvád telepen

militärischer Ausrüstung, Kleingerät, Münzen) (pp. 379-397). Kolloquien zur Vor- und Frühgeschichte, Band 22/1. Bonn: Habelt.

Soós, E. \& Tankó, K. (2018). Late Roman Period Quad settlement at Pásztó-Csontfalva. In L. Borhy, K. Dévai \& K. Tankó (eds.), Celto - Gallo - Roman Studies of the MTA-ELTE Research Group for Interdisciplinary Archaeology (pp. 281-301). Paris: L'Harmattan.

Tóth, K. (2014). Noteworthy findings of the Roman Age and Early Migration Period from Borsodszirák, Northeastern Hungary. First investigations. A Herman Ottó Múzeum Évkönyve 53, 159-182.

Varsik, Vl. (2011). Germánske osídlenie na vŷchodnom predpolí Bratislavy. Sídliská z doby rímskej v Bratislave-Trnávke a v okoli [Germán település Pozsony keleti határában. Római kori települések Pozsony Trnávka kerületében]. Archaeologica Slovaca Monographiae - Fontes 18. Nyitra: VEDA. 